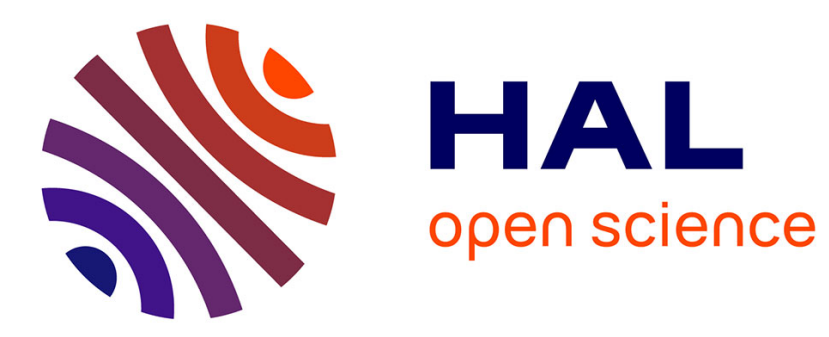

\title{
Autologous bone marrow cells and ischemic cardiomyopathy.
}

Jérôme Roncalli, Patricia Lemarchand

\section{To cite this version:}

Jérôme Roncalli, Patricia Lemarchand. Autologous bone marrow cells and ischemic cardiomyopathy.. Future Cardiology, 2011, 7 (5), pp.603-7. 10.2217/fca.11.46 . inserm-00642809

\section{HAL Id: inserm-00642809 https://www.hal.inserm.fr/inserm-00642809}

Submitted on 1 Sep 2012

HAL is a multi-disciplinary open access archive for the deposit and dissemination of scientific research documents, whether they are published or not. The documents may come from teaching and research institutions in France or abroad, or from public or private research centers.
L'archive ouverte pluridisciplinaire HAL, est destinée au dépôt et à la diffusion de documents scientifiques de niveau recherche, publiés ou non, émanant des établissements d'enseignement et de recherche français ou étrangers, des laboratoires publics ou privés. 


\section{Autologous bone marrow cells and ischemic cardiomyopathy}

Jerome Roncalli ${ }^{1}, \mathrm{MD}, \mathrm{PhD}$, Patricia Lemarchand ${ }^{2}, \mathrm{MD}, \mathrm{PhD}$.

${ }^{1}$ Department of Cardiology A, CIC-Biothérapies, INSERM U1048, Rangueil University Hospital, Toulouse, France.

${ }^{2}$ INSERM, UMR915, l'institut du thorax,Université de Nantes, UFR médecine CHU Nantes, Nantes, France.

Corresponding author:

Professor Jerome Roncalli

Department of Cardiology A, Rangueil University Hospital,

1, Avenue Jean Poulhès TSA50032

31059 Toulouse Cedex9, France

Tel:+33561323635;

Fax:+33561322246;

roncalli.j@chu-toulouse.fr 


\section{Summary}

Evaluation of: Intramyocardial stem cell injection in patients with ischemic cardiomyopathy: functional recovery and reverse remodeling.

Williams AR, Trachtenberg B, Velazquez DL, et al. Circ Res108, 792-6 (2011).

Transcatheter, intramyocardial injections of bone marrow-derived cells produce reverse remodeling in large animal models of ischemic cardiomyopathy. A variety of adult stem and progenitor cells from different sources have already been examined for their potential to promote cardiac repair and regeneration after myocardial infarction. This article reviews a recent study by Williams and colleagues who test the hypothesisthat transcatheter, intramyocardial injections of autologous bone marrow progenitor cells(mononuclear or mesenchymal stem cells) in left ventricular scar and border zone improve regional contractility of a chronic myocardial scar, and these changes predict subsequent reverse remodeling.All patients tolerated the procedure with no serious adverse events. At 1 year cardiac MRI demonstrated a decrease in end diastolic volume, a trend toward decreased end systolic volume, decreased infarct size, and improved regional LV function. This evaluation focuses on the findings and limitations of the study and provides bases for future promising clinical trials.

\section{Keywords}

Heart failure, Ischemic cardiomyopathy, MRI, Cardiac cell therapy, Mesenchymal stem cells 
This article reviews the recent paper by Williams et al.[1] showing that transcatheter intramyocardial injections of autologous bone marrow progenitor cells may improve regional contractility of a chronic myocardial scar, and that these changes predicted subsequent reverse remodeling. Heart failure $(\mathrm{HF})$ is a disease of increasing concern around the world. Fifty percent of all hospital admissions in patients over 65 years of age in the United States are for cardiac failure. It has a significant economic burden, and therapies today for these patients are limited. Stem cell therapy in this population has shown enormous promise to provide benefit to patients.A variety of adult stem and progenitor cells from different sources have already been examined for their potential to promote cardiac repair and regeneration after acute myocardial infarction (AMI). Although early, small-scale clinical studies underscored the potential effects of cell-based therapy largely by using bone marrow cells, subsequent randomized-controlled trials have revealed mixed results that might relate, at least in part, to differences in study design and techniques, e.g. differences in patient population, cell sources and preparation, and endpoint selection. Recent meta-analyses [2] have supported the notion that administration of bone marrow mononuclear cells (BMCs) may improve cardiac function on top of standard therapy after AMI and our group recently showed the effect of BMCs on myocardial viability [3]. Among the next steps, patients with chronic ischemic HF are potential targets for cell therapy because of the limits of available treatments and a lack of emerging therapies. Cardiac cell-based therapy currently also lacks clinical comparison studies of cell types, a situation of increasing concern given the growing number 
of cell types contemplated for therapy[4]. Focusing on these issues, Williams et al.[1] initiated a program of cell therapy using two types of bone marrow-derived stem cells, in which the pilot study is presented here.

\section{Methods}

In the study, eight patients with ischemic cardiomyopathy (4 months to 11 years after an AMI) received transendocardial injections in left ventricular (LV) scar and border zone of autologous bone-marrow-derived cells that had been harvested from iliac crest. Four patients were treated with BMCs and four with cultured mesenchymal stem cells (MSCs). The investigators used magnetic resonance imaging (MRI) to evaluate cardiac structure and function at baseline and at three, six, and 12 months after cell therapy. Only 4 patients had longitudinal assessment of scar size because of the presence of implantable cardioverter defibrillators. Thus, this study does not have a placebo nor control comparison group and lacks the power to identify any superiority between MSCs or BMCs.

\section{Results}

The primary outcome of this phase 1 study was to assess the safety of transendocardial administration, and none of the patients experienced a serious adverse event. Secondary endpoint analyses performed with MRI in 4/8 patients showed at 1 -year follow-up a decrease in end-diastolic volume $(p=0.03)$ and a trend toward decreased in end-systolic volume $(p=0.06)$ after cell administration compared to baseline. Authors stated a strong correlation between changes in 
end-systolic volume and end-diastolic volume with a parallel decrease in chamber volume. However, ejection fraction and left ventricular mass did not significantly change, but there was a significant decrease in infarct size of $18.3 \%$ $(p<0.05)$. The authors conclude that human autologous bone-marrow progenitor cells may increase regional contractility of injected myocardial scar tissue within three months of treatment, and these functional changes are associated with later reverse remodeling. Several limits are pointed out, including the small patient number and the lack of placebo or control group.

\section{Discussion}

In preclinical porcine studies, Hare's group previously demonstrated that transcatheter, intramyocardial injection of bone marrow-derived progenitor cells to chronically scarred myocardium improves LV regional function, reduces scar size, and creates reverse remodeling [5]. The translation of basic research described in this clinical trial occurs relatively early on in the evolution of this new field of research. What has been lost in translation is our understanding of the value of surrogate end points in cardiac cell therapy clinical trials [6]. Surrogate end points are useful ways of looking for effects that may have clinical relevance. Cardiac MRI represents a promising modality for a tissue characterization of AMI, beyond traditional morpho-functional indexes. Moreover, cardiac MRI parameters may in the future be used with greater frequency as surrogate imaging end points of morbidity and mortality for testing novel therapeutic strategies as in the case of cellular-based therapies[7, 8]. However, electronic devices such as pacemakers, 
defibrillators, infusion pumps, and others are still considered as contraindications in most of the patients, therefore preventing the use of MRI in patients at risk of having such devices, including patients with defibrillator because of low ejection fraction and HF (ESC guidelines 2010). Alternative methods for exploring myocardial viability also include nuclear imaging modalities[9](SPECT and PET), and low-dose dobutamine stress echocardiography.

The clinical relevance of small changes in surrogate measures with respect to their overall consequence is poorly understood. The literature is now full of similar small trials (Table 1 ) that were designed to test for safety but report effects despite a lack of statistical power. Although these trials demonstrated significant improvements in clinical outcome, they were associated with very small changes in cardiac function[4, 10]. MRI provides a unique opportunity to image the in vivo structural and functional changes after bone-marrow stem-cell therapy for the heart. Although, the infarction zone improvements were evident as early as 3 months and persisted out to 1 year and strongly correlated to the improvements in end-diastolic volume and end-systolic volume, the main limit of this study is the extrapolation of benefits with only 4 patients.

Comparing cell type administration

BMCs have already been administered in patients with ischemic cardiopathy [11,12]. Adult mesenchymal stem cells (MSCs) have shown promise for heart repair and have been explored for possible cardiac regeneration. The advantage of this cell population is the ease of acquisition and expansion in culture. 
However, their use in cardiac repair, as compared to bone marrow mononuclear cells is still at early stage. To date only two clinical trials have assessed the therapeutic potential of autologous MSCs for AMI $[13,14]$. In both studies, MSCs were selected by culture and have shown that intracoronary MSC administration is safe and feasible. So far, there is no available publication on intramyocardial administration of MSCs for chronic HF but only one study in the setting of refractory angina [15].

\section{Future Perspectives}

The study by Williams et al.[1] is the pilot phase of the Transendocardial Autologous Cells in Ischemic Heart Failure (TAC-THF) study (NCT00768066), aimed at evaluating the safety of cells administered via the BioCardia Helical Infusion Catheter (BioCardia, San Carlos, CA). TAC-HFT study will be the first study to compare BMCs and MSCs in humans in a phase II, randomized, doubleblinded, placebo-controlled study. The end points will be hospitalization plus death as well as the MRI end points used in the pilot study. Development of new systems for cell therapy product administration is of high interest since the number of patients with ischemic HF is increasing. Most often used in clinical trials (as referred to previous publications and referenced ongoing trials in clinicaltrials.org website), the NOGA mapping system has already been evaluated in humans but suffered from a long time period data acquisition allowing the 3D reconstruction of the left ventricle. However, in conjunction with the new NOGA® XP mapping system, new multi-electrode QwikStar® catheters 
(Biosense Webster) enable the sampling of several points simultaneously. This feature may allow the construction of maps with more points while decreasing manipulation of the LV cavity, resulting in shorter mapping times and greater mapping accuracy [16] to guide injections into viable zones. The TAC-HFT trial is built on the previous experience obtained in this Phase I, and the Phase I Transendocardial Autologous Bone Marrow in Myocardial Infarction (TABMMI) trial that treated ten patients and supported the safety of the procedure with patients showing sustained benefits [17].

As of April 27, 2011, only a few clinical trials currently recruiting patients with ischemic HF dedicated to treatment by autologous MSCs are ongoing and have been registered in clinicaltrials.org website. While the TAC-HFT trial is designed to compare BMCs and MSCs, the POSEIDON trial (NCT01087996) is comparing autologous and allogenic MSCs. However, there is still a need to compare MSCs versus placebo in order to show an effect of MSC therapy in ischemic HF. In this process, we are currently leading the phase I of the MESAMI (MESenchymal cell therapy And Myocardial Ischemia with decreased left ventricular function) program evaluating the safety of injecting MSCs directly into the heart to repair and restore heart function in patients who have chronic myocardial ischemia with HF (clinicaltrials.org NCT01076920). The multicenter randomized MESAMI phase 2 will be dedicated to evaluate versus placebo the effects of MSCs and preconditioned MSCs with melatonin following our recent findings [18]. 


\section{Executive summary}

Backgroung: Transcatheter, intramyocardial injections of bone marrow-derived cell therapy produces reverse remodeling in large animal models of ischemic cardiomyopathy.

Methods: Eight patients received transendocardial, intramyocardial injection of autologous bone marrow progenitor cells (mononuclear or mesenchymal stem cells) in left ventricular (LV) scar and border zone.

Results: All patients tolerated the procedure with no serious adverse events. CMR at 1 year demonstrated a decrease in end diastolic volume $(208.7 \pm 20.4$ versus $167.4 \pm 7.32 \mathrm{~mL} ; p=0.03$ ), a trend toward decreased end systolic volume (142.4 \pm 16.5 versus $107.6 \pm 7.4 \mathrm{~mL} ; p=0.06)$, decreased infarct size $(p<0.05)$, and improved regional LV function.

Discussion: These data suggest that transcatheter, intramyocardial injections of autologous bone marrow progenitor cells may improve regional contractility of a chronic myocardial scar, and these changes predict subsequent reverse remodeling.

Future perspectives: The findings support the potential clinical benefits of this new treatment strategy and ongoing randomized clinical trials. 


\section{References}

1. Williams AR, Trachtenberg B, Velazquez DL, et al.: Intramyocardial stem cell injection in patients with ischemic cardiomyopathy: functional recovery and reverse remodeling. Circ Res. 108, 792-6 (2011).

2. Abdel-Latif A, Bolli R, Tleyjeh IM, et al.: Adult bone marrow-derived cells for cardiac repair: a systematic review and meta-analysis. Arch. Intern. Med. 167, 989-997 (2007).

3. Roncalli J, Mouquet F, Piot C, et al:: Intracoronary autologous mononucleated bone marrow cell infusion for acute myocardial infarction: results of the randomized multicenter BONAMI trial. Eur. Heart J.in press (2011).

4. Tongers J, Losordo DW, Landmesser U. Stem and progenitor cell-based therapy in ischaemic heart disease: promise, uncertainties, and challenges. Eur. Heart J. 32, 1197-206 (2011).

5. Quevedo HC, Hatzistergos KE, Oskouei BN, et al.: Allogeneic mesenchymal stem cells restore cardiac function in chronic ischemic cardiomyopathy via trilineage differentiating capacity. Proc. Natl. Acad. Sci. U S A 106, 14022-7 (2009).

6. Lovell MJ, Mathur A. Cardiac stem cell therapy: progress from the bench to bedside. Heart 96,1531-7 (2010).

7. Perazzolo Marra M, Lima JA, lliceto S. MRI in acute myocardial infarction. Eur. Heart J. 32,284-93 (2011). 
8. Schwitter J, Arai AE. Assessment of cardiac ischaemia and viability: role of cardiovascular magnetic resonance. Eur. Heart J.32, 799-809 (2011).

9. Dobrucki LW, Sinusas AJ. PET and SPECT in cardiovascular molecular imaging. Nat. Rev. Cardiol. 7, 38-47 (2010).

10. Alaiti MA, Ishikawa M, Costa MA. Bone marrow and circulating stem/progenitor cells for regenerative cardiovascular therapy. Transl. Res. $156,112-29(2010)$.

11. Tse HF, Kwong YL, Chan JK, Lo G, Ho CL, Lau CP. Angiogenesis in ischaemic myocardium by intramyocardial autologous bone marrow mononuclear cell implantation. Lancet 361, 47-9 (2003).

12. Fuchs S, Kornowski R, Weisz G, et al.: Safety and feasibility of transendocardial autologous bone marrow cell transplantation in patients with advanced heart disease. Am. J. Cardiol. 97, 823-9 (2006).

13. Chen SL, Fang WW, Ye F, et al.: Effect on left ventricular function of intracoronary transplantation of autologous bone marrow mesenchymal stem cell in patients with acute myocardial infarction. Am. J. Cardiol. 94, 92-5 (2004).

14. Katritsis DG, Sotiropoulou PA, Karvouni E, et al.: Transcoronary transplantation of autologous mesenchymal stem cells and endothelial progenitors into infarcted human myocardium. Catheter. Cardiovasc. Interv. 65, 321-9 (2005). 
15. Friis $\mathrm{T}$, Haack-Sorensen M, Mathiasen AB, et al.: Mesenchymal stromal cell derived endothelial progenitor treatment in patients with refractory angina. Scand. Cardiovasc. J.45, 161-8 (2011).

16. Fernandes MR, Silva GV, Zheng Y, et al.: Validation of QwikStar Catheter for left ventricular electromechanical mapping with NOGA XP system. Tex. Heart Inst. J. 35, 240-4 (2008).

17. de la Fuente LM, Stertzer SH, Argentieri J, et al.: Transendocardial autologous bone marrow in chronic myocardial infarction using a helical needle catheter: 1-year follow-up in an open-label, nonrandomized, singlecenter pilot study (the TABMMI study). Am. Heart J. 154, 79 e1-7 (2007).

18. Mias C, Lairez O, Trouche E, et al.: Mesenchymal stem cells promote matrix metalloproteinase secretion by cardiac fibroblasts and reduce cardiac ventricular fibrosis after myocardial infarction. Stem Cells 27, 2734-43 (2009).

19. Strauer BE, Brehm M, Zeus T, et al:: Regeneration of human infarcted heart muscle by intracoronary autologous bone marrow cell transplantation in chronic coronary artery disease: the IACT Study. J. Am. Coll. Cardiol. 46, 1651-8 (2005).

20. Perin EC, Dohmann HF, Borojevic R, et al.: Transendocardial, autologous bone marrow cell transplantation for severe, chronic ischemic heart failure. Circulation 107, 2294-302 (2003). 
21. Assmus B, Honold J, Schachinger V, et al.: Transcoronary transplantation of progenitor cells after myocardial infarction. N. Engl. J. Med. 355, 12221232 (2006).

22. Assmus B, Fischer-Rasokat U, Honold J, et al.: Transcoronary transplantation of functionally competent BMCs is associated with a decrease in natriuretic peptide serum levels and improved survival of patients with chronic postinfarction heart failure: results of the TOPCARECHD Registry. Circ. Res. 100, 1234-41 (2007).

23. van Ramshorst J, Bax JJ, Beeres SL, et al.: Intramyocardial bone marrow cell injection for chronic myocardial ischemia: a randomized controlled trial. JAMA 301, 1997-2004 (2009).

24. Diederichsen AC, Moller JE, Thayssen P, et al:: Effect of repeated intracoronary injection of bone marrow cells in patients with ischaemic heart failure the Danish stem cell study--congestive heart failure trial (DanCell-CHF). Eur. J. Heart Fail. 10, 661-7(2008).

25. Ang KL, Chin D, Leyva F, et al.: Randomized, controlled trial of intramuscular or intracoronary injection of autologous bone marrow cells into scarred myocardium during $C A B G$ versus $C A B G$ alone. Nat. Clin. Pract. Cardiovasc. Med. 5, 663-70 (2008).

26. Losordo DW, Schatz RA, White CJ, et al.: Intramyocardial transplantation of autologous CD34+ stem cells for intractable angina: a phase I/lla double-blind, randomized controlled trial. Circulation 115, 3165-3172 (2007). 
27. Tse HF, Thambar S, Kwong YL, et al.: Prospective randomized trial of direct endomyocardial implantation of bone marrow cells for treatment of severe coronary artery diseases (PROTECT-CAD trial). Eur. Heart J. 28, 2998-3005 (2007).

28. Strauer BE, Yousef M, Schannwell CM. The acute and long-term effects of intracoronary Stem cell Transplantation in 191 patients with chronic heARt failure: the STAR-heart study. Eur. J. Heart Fail.12, $721-9$ (2010). 
Table 1: Published clinical trials of cardiac cell therapy using bone marrow-derived cells in patients with chronic ischemic heart disease associated or not with decreased left ventricular function.

\begin{tabular}{|c|c|c|c|c|c|c|c|}
\hline Study & Design & $\begin{array}{l}\text { Patien } \\
\text { numbe }\end{array}$ & Disease & $\begin{array}{l}\text { Cell } \\
\text { type }\end{array}$ & $\begin{array}{l}\text { Follow-Up } \\
\text { (months) }\end{array}$ & Primary End Point & $\begin{array}{l}\text { Imaging } \\
\text { Modalities }\end{array}$ \\
\hline IACT[19] & NonRCT & 18 & Chronic MI & $\mathrm{BMC}$ & 3 & LVEF & $\begin{array}{l}\text { LV angio, } \\
\text { SPECT, PET }\end{array}$ \\
\hline Tse et al.[11] & NonRCT & 8 & $\begin{array}{l}\text { Severe ischaemic heart } \\
\text { disease }\end{array}$ & $\mathrm{BMC}$ & 3 & safety & LV angiography \\
\hline Perin et al.[20] & $\mathrm{RCT}$ & 21 & $\begin{array}{c}\text { Severe, chronic ischemic heart } \\
\text { failure }\end{array}$ & BMC & $2-12$ & myocardial perfusion & LV angiography \\
\hline $\begin{array}{l}\text { TOPCARE- } \\
\text { CHD[21] }\end{array}$ & $\mathrm{RCT}$ & 75 & Stable ischemic heart disease & $\mathrm{BMC}$ & 3 & LVEF & $\begin{array}{l}\text { LV angiography, } \\
\text { MRI }\end{array}$ \\
\hline $\begin{array}{l}\text { TOPCARE- } \\
\text { CHD } \\
\text { registry[22] }\end{array}$ & Registry & 121 & Stable ischemic heart disease & $\mathrm{BMC}$ & 18 & $\begin{array}{c}\text { NTpro-BNP, NTpro- } \\
\text { ANP }\end{array}$ & LV angio, SPECT \\
\hline Fuchs et al.[12] & nonRCT & 27 & Refractory angina & $\mathrm{BMC}$ & $3-12$ & safety & \\
\hline $\begin{array}{c}\text { van Ramshorst } \\
\text { et al.[23] }\end{array}$ & $\mathrm{RCT}$ & 50 & Chronic myocardial ischemia & $\mathrm{BMC}$ & 6 & myocardial perfusion & MRI \\
\hline $\begin{array}{c}\text { Diederichsen et } \\
\text { al.[24] }\end{array}$ & NonRCT & 32 & Congestive heart failure & $\mathrm{BMC}$ & 4 & LVEF & MRI \\
\hline Friis et al.[15] & NonRCT & 31 & Refractory angina & MSC & 6 & $\begin{array}{c}\text { changes in perfusion } \\
\text { defects }\end{array}$ & Echocardiography \\
\hline Ang et al.[25] & NonRCT & 63 & Chronic MI & $\mathrm{BMC}$ & 6 & $\begin{array}{l}\text { LV segmental wall } \\
\text { motion }\end{array}$ & $\mathrm{MRI}$ \\
\hline TABMMI[17] & NonRCT & 10 & Chronic MI & $\mathrm{BMC}$ & 12 & LVEF & Echocardiography \\
\hline Losordo et & $\mathrm{RCT}$ & 24 & Refractory angina & CD34+ & 6 & safety & \\
\hline
\end{tabular}




\begin{tabular}{|c|c|c|c|c|c|c|c|}
\hline al.[26] & & & & & \\
\hline $\begin{array}{c}\text { PROTECT- } \\
\text { CAD[27] }\end{array}$ & RCT & 28 & $\begin{array}{c}\text { Severe coronary artery } \\
\text { disease }\end{array}$ & BMC & 6 & LVEF & SPECT, MRI \\
\hline STAR[28] & NonRCT & 191 & $\begin{array}{c}\text { Ischemic cardiomyopathy } \\
\text { BMC }\end{array}$ & 60 & LVEF & LV angiography \\
\hline
\end{tabular}

RCT: randomized clinical trial, BMC: bone marrow cells, MSC: mesenchymal stem cells, Ml, myocardial infarction, LVEF: left ventricular ejection fraction. 